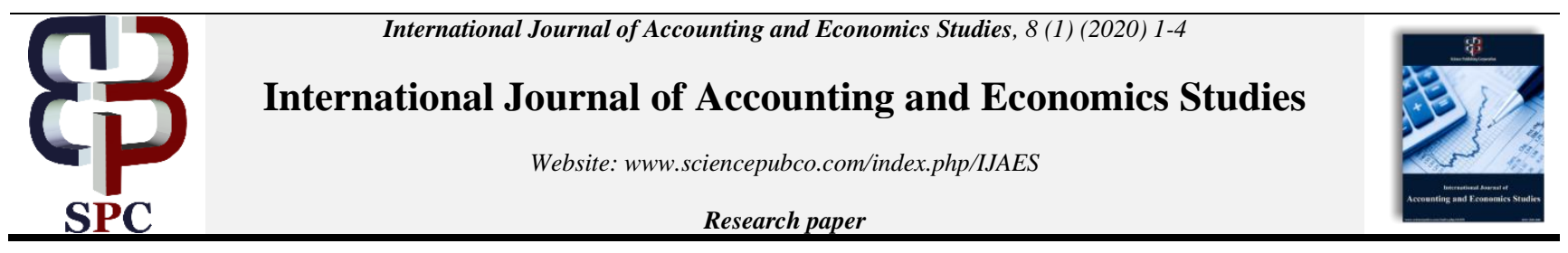

\title{
Determining fair remuneration based on human capital theory
}

\author{
Olaf Hynek*, Marcin Bik \\ *Corresponding author E-mail: olafh@onet.eu
}

\begin{abstract}
The text of Determining fair remuneration based on human capital theory contains useful informations about measurability human capital that can be used for personal use in any case of employment in any country. the text contains the essence of fair remuneration, the formulas needed to create it, and 2 examples of their application.
\end{abstract}

Keywords: Remuneration; Fair; Human; Capital; Costs.

\section{Introduction}

The following article presents the nature of fair remuneration, which guarantees a decent standard of living. The attempt to determine the level of fair pay has been made by the Committee of Independent Experts of the Council of Europe. This committee considered that the starting point for determining the level of this pay should be the average pay. Based on numerous concepts of remuneration systems in modern economics, we are able to determine the value of the human capital, which is defined by the theory of Arthur Pigou that arose in the 60 s of the twentieth century saying that a human is the most valuable resource of enterprise. Given this theory, we can identify those qualities and skills that make people productive. The first part of the article presents these measurement models with the help of which we can discern the increase in human capital and present its values.

\section{Models of measuring human capital}

Although most of the famous economists presented their reflections on capital, until recently there was no clear theory explaining the essence of this important category. Nowadays, there is a growing conviction [Dobija, 2015; Renkas, 2013] that the capital should be seen as an abstract and potential category and be defined as the object's ability to do work.

The most general formula for capital growth is the compound interest formula. Its significant feature is the occurrence of initial capital C0, which is an expression of the principle that the capital is not created from nothing. Only the already owned capital can grow due to work processes or change due to distraction. According to the authors [Dobija, Kurek, 2013; Dobija, 2011] the general capital growth model is as follows:

$\mathrm{C}_{\mathrm{t}}=\mathrm{C}_{0} \mathrm{e}^{(\mathrm{p}-\mathrm{s}+\mathrm{m}) \mathrm{t}}, \mathrm{p}=\mathrm{E}(\mathrm{s})=\mathrm{E}(\mathrm{s})=0,08[1 /$ year $]$,

Where:

C0 - initial capital,

$\mathrm{p}$ - economic constant of potential growth,

$\mathrm{s}$ - the rate of natural, spontaneous dispersion of capital,

$\mathrm{m}$ - rate of capital increase as a result of the work performed.

The interpretation of the forces that act in the law of exponential growth is as follows:

ept - a factor that determines the natural potential for capital growth, i.e. the impact of

nature; economic constant $\mathrm{p}=0.08[1 /$ year $]$,

e-st - a factor that determines the spontaneous dispersion of capital, i.e. the operation of the thermodynamic time arrow (the second law of thermodynamics), $\mathrm{t}$ - calendar time,

emt - capital inflow through labor, which weakens the influence of the thermodynamic arrow of time.

The general capital model leads to the formulation of a human capital growth model. Assuming that in formula (1) the variable m eliminates the variable $s$, the constant $\mathrm{p}$ has a fundamental impact on the growth of human capital:

$\mathrm{H}=\mathrm{H}_{0} \mathrm{e}^{\mathrm{pt}}$,

Where: 
p - economic constant of potential growth,

$\mathrm{t}$ - passage of time.

Note, however, that the constant also limits the growth rate (a child cannot grow $40 \mathrm{~cm}$ in a week).

The model of human capital of a person without professional education and professional experience is presented in the formula:

$\mathrm{H}(\mathrm{k}, \mathrm{p})=\mathrm{K}$,

Where:

$\mathrm{H}(\mathrm{k}, \mathrm{p})$ - value of human capital,

$\mathrm{K}$ - capitalized maintenance costs $\mathrm{k}$ using the capitalization rate $\mathrm{p}$.

Continuous capitalization is used, which leads us to the following formula:

$\mathrm{K}=\mathrm{k} \cdot 12 \frac{\mathrm{e}^{\mathrm{pt}}-1}{\mathrm{p}}$

Where: $\mathrm{K}$ - capitalized living costs,

$\mathrm{k}$ - monthly maintenance costs,

$\mathrm{p}$ - economic constant $(0.08), \mathrm{t}$ - number of years of life

The model of human capital of a working person includes an additional variable related to the professional experience acquired during work [Cieślak, Dobija, 2007, pp. 5-24]:

$\mathrm{H}(\mathrm{k}, \mathrm{e}, \mathrm{T}, \mathrm{p})=(\mathrm{K}+\mathrm{E}) \mathrm{x}[1+\mathrm{Q}(\mathrm{T})]$,

where:

$\mathrm{H}(\mathrm{k}, \mathrm{e}, \mathrm{T}, \mathrm{p})$ - the value of capital attributed to a person with experience of $\mathrm{T}$ years of work,

$\mathrm{K}$ - capitalized living costs,

E - capitalized education costs,

$\mathrm{Q}(\mathrm{T})$ - factor of experience increase with the passage of T years of work.

Size Q (T) is derived from a known learning curve [Stańdo-Górowska, 2014].

$\square$ The above model can also be presented in an additive form [Kozioł, 2010a, pp. 79-80]:

$\mathrm{H}(\mathrm{k}, \mathrm{e}, \mathrm{T}, \mathrm{p})=\mathrm{K}+\mathrm{E}+\mathrm{D}(\mathrm{T})$

Where:

$\mathrm{D}(\mathrm{T})$ means the capital from the experience of professional work performed for T years and $\mathrm{D}(\mathrm{T})=\mathrm{H}(0) \times \mathrm{Q}(\mathrm{T})$, where $\mathrm{D}(0)=0$. This model is more convenient for analyzing and determining remuneration

W. Kozioł [2010b] developed separate models for employees continuing education and incurring expenses in this respect. These models take into account the size of the capitalized costs for obtaining the degree qualification (where ti is the number of years from the receipt of the relevant degree until the measurement).

Therefore, based on the above model of measuring employees' human capital, the amount of fair remuneration can be determined.

\section{The essence of fair remuneration}

Understanding that capital is the ability to do work is an important moment in the development of economic sciences. This term identifies the fundamental principles underlying the concept of capital. It is worth noting that the ability to perform work is also a basic category in physical sciences. As known, this statement comes from William Thomson.

To explain the essence of fair remuneration, it is necessary to understand that if life requires the heat engines to function, which can work only under the condition of dissipation of some energy, then for life to exist, this natural loss must be compensated. Therefore, remuneration for the work done should at least balance the natural dispersion of human capital. In the capital model, the level of scattering is determined by the variable $\mathrm{s}$, whose average value, as research shows, is $\mathrm{p}=\mathrm{E}(\mathrm{s})=0.08[1 /$ year $]$.

The economic constant of potential growth determines the fair level of the minimum wage [Renkas, 2016b], which compensates for the spontaneous dispersion of the individual human capital of the employee. These are important issues that make up the labor economy being formulated [Dobija 2015; Renkas, 2016a, 2017]. This theory refers to the knowledge that existed in ancient civilizations, such as: Mesopotamia, Egypt, and classical economics not dominated by theories of central banking. In this economy, work is a basic category, and fair remuneration creates amounts due for work exchanged for products

To explain the essence of fair remuneration, it is crucial to understand that it should at least balance the natural dispersion of human capital. In the capital model (1), the level of scattering is determined by the variable $\mathrm{s}$, whose average value, as research shows, is $\mathrm{p}=\mathrm{E}$ ( $\mathrm{s}$ ) $=0.08$ [1 / year]. Thus, the formula for determining fair remuneration $(\mathrm{W})$ is as follows:

$\mathrm{W}=0,08 \times \mathrm{H}(\mathrm{p})$

Where:

$\mathrm{H}(\mathrm{p})$ - value of human capital,

$\mathrm{W}$ - fair remuneration

Based on this model, we estimate the value of human capital and fair remuneration on the example of the authors of this article. 


\section{Case study}

Below there are presented two examples of calculations together with the results compared to the fair remuneration calculated on the basis of seniority and completed internship in college.

The first example refers to an employee of the company "Let's Paint It" who performs artistic murals on behalf of; The second example is an employee of the company "Clean Cost Customs" dealing with comprehensive cleaning of passenger car interiors.

$$
\begin{aligned}
& \mathrm{K}=\mathrm{k} \times 12 \times \frac{\mathrm{e}^{\mathrm{p} \times \mathrm{t}-1}}{\mathrm{P}}=932 \times 12 \times \frac{2,72^{0.08 \times 23}-1}{0,08}=11184 \times \frac{2,72^{1,84}-1}{0,08}=11184 \times \frac{6,30-1}{0,08}=11184 \times \frac{5,30}{0,08}=11184 \times 66,25=740940 \\
& \mathrm{E}=\mathrm{e} \times 12 \times \frac{\mathrm{e}^{\mathrm{p} \times \mathrm{t}}-1}{\mathrm{P}}=5000 \times 12 \times \frac{2,72^{0.08 \times 4}-1}{0,08}=5000 \times \frac{2,72^{0,32}-1}{0,08}=5000 \times \frac{0,37}{0,08}=5000 \times 4,71=23587 \\
& \mathrm{D}(\mathrm{t})=(\mathrm{K}+\mathrm{E}) \times \mathrm{Q}(\mathrm{t})=(740940+23587) \times\left(1-2^{\frac{-0.045}{0,30}}\right)=764527 \times\left(1-2^{-0,15}\right)=764527 \times 0,10=76452 \\
& H(t)=K+E+D(t)=740940+23587+76452=840979 \\
& \mathrm{~W}=0.08 \times \mathrm{H}(\mathrm{t}) \\
& \mathrm{W}=0.08 \times 840979 \\
& \mathrm{~W}=67278 \\
& \mathrm{~W}_{12}=67278 \div 12 \\
& \mathrm{~W}_{12}=5606,52 \\
& \mathrm{~K}=\mathrm{k} \times 12 \times \frac{\mathrm{e}^{\mathrm{p} \times \mathrm{t}}-1}{\mathrm{P}}=932 \times 12 \times \frac{2,72^{0.08 \times 21}-1}{0,08}=11184 \times \frac{2,72^{1,68}-1}{0,08}=11184 \times \frac{5,37-1}{0,08}=11184 \times \frac{4,37}{0,08}=11184 \times 54,625=611472 \\
& \mathrm{E}=\mathrm{e} \times 12 \times \frac{\mathrm{e}^{\mathrm{p} \times \mathrm{t}}-1}{\mathrm{P}}=5000 \times 12 \times \frac{2,72^{0.08 \times 2}-1}{0,08}=5000 \times \frac{2,72^{0,16}-1}{0,08}=5000 \times \frac{0,17}{0,08}=5000 \times 2,125=10625 \\
& \mathrm{D}(\mathrm{t})=(\mathrm{K}+\mathrm{E}) \times \mathrm{Q}(\mathrm{t})=(611472+10625) \times\left(1-2^{\frac{-0.045}{0,30}}\right)=622097 \times\left(1-2^{-0,15}\right)=764527 \times 0,10=62209,7 \\
& H(t)=K+E+D(t)=611472+10625+62209,7=684306,7 \\
& \mathrm{~W}=0.08 \times \mathrm{H}(\mathrm{t}) \\
& \mathrm{W}=0.08 \times 684306,7 \\
& \mathrm{~W}=54744,53 \\
& \mathrm{~W}_{12}=54744,53 \div 12 \\
& \mathrm{~W}_{12}=4562,04
\end{aligned}
$$

In Poland, the employer incurs additional costs in connection with hiring an employee at the level of $20.6 \%$. Now we will compare the fair wages with those actually received.

Table 1:

\begin{tabular}{llll}
\hline & Fair remuneration & Actual remuneration & Compliance Percentage \\
\hline Entity 1 & 5606,52 & 5500 & $98 \%$ \\
Entity 2 & 4562,04 & 4300 & $94 \%$ \\
\hline
\end{tabular}

As we can see from table number 1 - the percentage of compliance is high, which indicates a decent salary in both cases. Thus, capital theory can be used to determine fair remuneration.

\section{Conclusion}

Determining fair remuneration based on the theory of human capital is a proven theory and can be applied in any country, taking into account the minimum earnings in a given country. Given the content of the above article, and assuming that any jobseeker would follow the above guidelines and impose them on a future employer, the average standard of living in a particular country would rise significantly thanks to the theory of human capital.

\section{Acknowledgement}

Special thanks to Zuzanna Biernat for translating of the above text. 


\section{References}

[1] Cieślak I., Dobija M. (2007), Teoretyczne podstawy rachunkowości kapitału ludzkiego, Zeszyty Naukowe, nr 735, Kraków: Akademia Ekonomiczna w Krakowie, ss. 5-24.

[2] Dobija M. (2011), Abstract nature of money and the modern equation of exchange, Modern Economy, vol. 2, s. 142-152, https://doi.org/10.4236/me.2011.22019.

[3] Dobija M. (2015), Laborism. The economics driven by labor, Modern Economy, vol. 6, no. ??s. 578-594. https://doi.org/10.4236/me.2015.65056

[4] Dobija M., Kurek B. 2013), Towards Scientific Economics, Modern Economy, vol. 4, no. 4, s. 293-304. https://doi.org/10.4236/me.2013.44033.

[5] Kozioł W. (2010a), Pomiar kapitatu ludzkiego jako podstawa ksztaltowania relacji ptac w organizacji (rozprawa doktorska), Uniwersytet Ekonomiczny w Krakowie, Kraków.

[6] Kozioł W. (2010b), Kształtowanie wynagrodzeń podstawowych nauczycieli akademickich na podstawie pomiaru kapitatu ludzkiego i intelektualnego, Nierówności społeczne a wzrost gospodarczy, Zeszyt Nr 16, s. 280-290.

[7] Renkas J. (2017), Wynagrodzenie minimalne a produktywność pracy w gospodarce, Zeszyty Naukowe Uniwersytetu Ekonomicznego w Katowicach, Nr 341, s. 300-315.

[8] Renkas J. (2013), Wage Expectations in Light of Human Capital Measurement Theory, Argumenta Oeconomica Cracoviensia, 9/2013, Wydawnictwo Uniwersytetu Ekonomicznego w Krakowie, Kraków, s. 29-42. https://doi.org/10.15678/AOC.2013.0902.

[9] Renkas J. (2016a), Ekonomia pracy: teoria godziwych wynagrodzeń, Prace Naukowe Uniwersytetu Ekonomicznego we Wrocławiu, Zeszyt 439, s. 284-301. https://doi.org/10.15611/pn.2016.439.25.

[10] Renkas J. (2016b), Nierówności płacowe a stała ekonomiczna potencjalnego wzrostu, Nierówności Społeczne a Wzrost Gospodarczy, Zeszyt nr 47(3), s. 466-480, https://doi.org/10.15584/nsawg.2016.3.34.

[11] Stańdo-Górowska H. (2014), Oczekiwania płacowe studentów, a model kapitału ludzkiego, Zeszyty Naukowe Uniwersytetu Ekonomicznego w Krakowie, red. A. Pocztowski, nr 4(928), s. 51-59. https://doi.org/10.15678/ZNUEK.2014.0928.0404. 